\title{
Developments in Promotion Strategies: Review on Psychological Streams of Consumers
}

\author{
Syed Hasnain Alam Kazmi ${ }^{1}$ \\ ${ }^{1}$ School of Economics and Management, Southwest Jiaotong University, Chengdu, Sichuan, China \\ Correspondence: Syed Hasnain Alam Kazmi, School of Economics and Management, Southwest Jiaotong \\ University, Chengdu, Sichuan, China. Tel: 86-159-0284-4074. E-mail: hasnain@my.swjtu.edu.cn
}

Received: April 22, 2015

Accepted: May 5, 2015 Online Published: May 31, 2015

doi:10.5539/ijms.v7n3p129

URL: http://dx.doi.org/10.5539/ijms.v7n3p129

\begin{abstract}
Theoretical decision-making models and theories in context to promotions at both brand and product level have focused and studied on several thought-provoking research explorations with three steams of research in promotion strategies. Researchers have studied the impact of price promotion strategies on consumers in several distant behaviors. Developmental theoretical models provide managers and researchers insights with deep understandings for many vital concerns like, why need in-depth study to the practice of promotion strategies, dilemmas like stock pressure, sales promoting decline after promotion events and its consequences. Branding and pricing have vital influence on decisions by consumers. Psychophysiological models are useful in the context, for instance, in decision and media research. Many theoretical researches in promotions have focused its aspects on pricing and its impact on consumer decision making. This is might because much of the literature has focused on building and evaluating price promotion strategies. This paper provides an indepth review on theoretical models, which are valuable for both researchers and for marketing executives.
\end{abstract}

Keywords: decision-making models, promotion strategies, theory, consumer, brand, sales promotion

\section{Introduction}

\subsection{The Perspectives of Consumers'Mental Response}

Extensive literature on promotion strategies focused on three broad-spectrum streams of study.

The first stream focuses on the empirical estimation of pricing in promotions on aggregate market consequences for instance market shares, sales, with brand switching. These streams of investigations are descriptive and measures the depths of the promotional spike in promotions and the elasticity in pricing (like; Guadgani \& little, 1983; Kamakura \& Russell, 1989) on promotion post repeat purchases (Shoemaker \& Shoaf, 1977; Dodson et al., 1978).

The second course of study focuses on recognizing the promotion customer's sensitiveness in relations to behaviors, and psychosomatic properties. This spectrum portrays on promotion sensitivity in customers with context to variables, for instance; income group, household and its size, ages and genders (e.g., Mittal, 1994; Ehrenberg, Hammond \& Goodhardt, 1994; Huff \& Alden, 1998).

The third stream of investigation inspects on the psychological impact in promotion strategies on customer behavior and their choice abilities. It practices mental aspects and modeling to enlighten on the customer responding to promotion strategies (scholars like; Huff \& Alden, 1998; Chandon, Wansink \& Laurant, 2000; Buil et al., 2013a, b).

In current review study, the theoretical strategies used for consumers' mental response to promotions are studied. Extensive empirical work indicates that the hypothetical methodologies have a sole product focusing for assessing buyer response to promotion strategies. The paper recommend and discuses on theoretical perception to evaluate consumer response to promotion strategies. This viewpoint used to investigate and explore psychological and strategic developments leading to optimistic cross product, cross culture and cross-national influence in promotions.

\section{Literature Review and Model Developments}

Many theoretical researches in promotions have focused its aspects on pricing and its impact on consumer 
decision making. This might because much of the literature has focused on building and evaluating price promotion strategies. Theoretic models are discussed, which are used for the study of price promotions.

\subsection{Theoretical Models: Inside Your Mind}

Scholars have studied the impact of price promotion strategies on consumers' reference internal pricing (Lattin \& Bucklin, 1989; Kalwani \& Yim, 1992) and the effect of the relative price advertising to buyer sensitivity of savings obtaining in from of pricing campaigns (Berkowitz \& Walton, 1980; Urbany, Bearden, \& Weilbaker, 1988; Bearden, Lictenstein, \& Teel, 1984; Buil et al., 2013a, b). Theoretical methods that are used for the study of pricing aspect of the promotion, include:

\section{* Theories of Adaptation level \\ * Assimilation Contrast \\ * Self Perception Theory \\ * The Objective Perception Theory \\ * Prospect Model Theory \\ * Mental Accounting Theory \\ * Theory of the Reasoned Action \\ * Theory of Planned Behavior \\ * Theory of Attribution \\ * Transaction Utility \\ * Attitude Model \\ * Model of Elaboration Likelihood}

\subsubsection{Adaptation Level Theory}

Monroe (1973) suggests that customers carry an adaptation level with them in pricing or in 'internal reference price' for a given item for consumption or product. The internal reference pricing characterizes the price on a customer level to assume to give/pay for a given brand or a product and is shaped based by the earlier prices paid or observed for either the identical products or alike products. The internal reference price said to be the standard in contradiction of marketplace prices that are associated and/or judged as in form of medium, high or low pricing. Laboratory experiments have established its existence in literature (Gurumurthy \& Winer, 1995).

Literature suggested on the buyers' reaction to the sales price promotion established on the relationships in-between promotional price and internal reference pricing (such as explain by Lattin \& Bucklin, 1989; Kalwani \& Yim, 1992). Repeated promotions may establish consumers toward inferior the price reference of promoted brand/product. Customers may be reluctant to pay some price for the products when the price promotion was finished with lower reference prices. Winer (1986) studied the reference price effects in context to model of linear probability on brand choice.

Kalwani, Rinne, Sugita and Yim (1990) examine the customer choice and decisions of brand that is mediated from consumers' price prospects. Authors presented that customers' price prospects were establish on former prices of the product/brand. Studied by the experimentations, the relative effect of the internal reference price in the thoughts and external price reference as provided by particular stimulus on customer brand choice projected the choice with binary types of price references and had a significant impact on purchase possibilities (Mayhew \& Winer 1992). Scholars proposed customers idealized reference opinions for the price and the promotion activities. These reference opinions are grounded on preceding experience to promotions and prices on consumers' brand choice. Lattin and Bucklin (1989) study that, discounting in price may haze the discrepancy among the regular price to promotional pricing of the brand. Kalwani and Yim (1992) explored on the impacts of frequency in promotion and the penetration of discount price on brand's projected brand and pricing choices. Authors have demonstrated that the promotions' frequency and depths of the price discount have substantial effect on price prospects. Similar to the study Lattin and Bucklin, (1989) proposed on the consumers that they form mutually promotion and price expectations for the frequently promoted product. Customers will expect to form price judgements and its promoted effect when a product is offered at lower promoted price.

An implied theory of price sensitivity focuses on it that, illustrates customers notice the values of products when they will purchase the brand. Empirical work (Kalwani \& Yim, 1992; Mayhew \& Winer, 1992; Kalwani, Rinne, Sugita, \& Yim, 1990) has done and shows chain of responses and prices that have been stimulated. 
In some empirical work, it is shown that the internal price to reference was not openly measure but characterized through some proxy methods of preceding prices (like work of Gurumurthy \& Winer, 1995). Examination that have been executed in real life situations revealed that customers have a blurred notion in price values for repeatedly purchased goods and cannot correctly name the price of items, just put in the shop dray (Dickson \& Sawyer, 1990; Davis, Inman, \& Mcalister, 1992).

Because price promotions diminish the buyer price reference for a brand, this theoretical method envisages undesirable long term influence on price promotions. Nevertheless, many empirical works suggest that at aggregate marketplace level has found that promotions have no long term undesirable consequences. This pricing concept is beneficial in enlightening customer response in context in promotions that will lessen the pricing of brand and influence the price reference. However, it can be said that, non-price promotions may not trivial the price of the brand or the product and its impact proceeding to internal reference pricing (Campbell \& Diamond, 1990; Buil et al., 2013a). Therefore, it can be concluded that this theoretical methodology may not be very beneficial in enlightening customer response to non-price based promotions, for instance; free gifts and extra product deals.

\subsubsection{Theory of the Assimilation}

It contrast observe on the external price referencing and how will it will affect the internal pricing reference of consumers' with subsequent promotion evaluations. It states that, an external price referencing is moderated more than buyer's internal price reference and will be perceive to be reliable and adapted. The effect of adaptation will finally be result in the shift of internal pricing reference towards external reference price at higher level and will be a parallel surge in favorability for promotion estimations. Nevertheless, if reference external pricing surpasses the maximum expected steady pricing level, it can be observed in an incredible and henceforth analogized with the pricing internal standards levels. Literature work established in view to the theory of the adaptation have presented that promotional announcements including external price reference yield developed perception of savings than ads which comprise only lower price promotions (Berkowitz \& Walton, 1980; Urbany, Bearden \& Weilbaker, 1988; Bearden Lichtenstein \& Teel, 1984).

Scholars established the value of a price promotion although have high external prices reference nevertheless are somewhat at cut-rate, it accomplish to advance customer views (Urbany, Bearden, \& Weilbaker, 1988).

Martin and Monroe (1994) establish that, in the promotions tactics, the consumer perception of price fairness will be base not only on comparison among internal reference and price discounting, but correspondingly the proportional difference of the prices paid by customers.

\subsubsection{Attribution Theory}

This theoretical concept defines the shopper's way to enlighten the sources in trials (Mizerski, Golden, \& Kernan, 1979) in dissimilar categories for attribution level and it will be discriminate based on the specific entity about which the ascription was existed. Attributions based on self (like; 'why I would buy it'?) is derived under self perceive model while the object perception theory lies in context to the attributions based on an object or a product/brand lies under it.

\subsubsection{Self Perception Theory}

Scholars study the phenomenon of the theory of self perception with regard to promotions and depict that the buying in the existence of the robust promotions will likely to guide buyer to trait buying to the exterior source (promotion) rather than the internal one (likeness for a brand). This could lead to the disregarding of auspicious brands and attitude and will weaken repeat purchase intensions of buyers. Fundamentally, self-perception philosophy proposes a damaging or contrary long-term effect for promotions (price) and its strategies on customer behaviors. Scholars like, Dodson, Tybout and Sternthal (1978) studied dissimilar types in promotions in context to price to coupons, cents off bundles and packaged in coupons that followed the perception concept to enlighten on the effects and lead to lower prospect for repeat buying behaviors.

Neslin and Shoemaker (1989) enlighten an unconventional clarification for the lower repeat buying for promotion and stated that minor repeat purchases may well be establish after the promotion (price) even single buying prospects remain alike before and after the price campaigns. Its reason is that, promotional pricing for the time being fascinates an irregular number of homes whom underneath the un-promotional settings that will have low intensity of purchasing the product. Therefore, it will bring down the average repurchase frequency. In low-level involvement Brands/Products, customers are likely unable to driven adequately to for the thoughtful provenances proposed by the theory of self-perception. 


\subsubsection{Object Perception Theory}

The theory of object perception to the promotions implies the presence of promotion tools/tactics/strategies, which will guide the customers to attribute for low value to Product/Brand since will be on promotional campaign. Nevertheless, attributions of quality in lower to endorsed product expected to hinge on the elements for instance, regularity and the uniqueness of the price to it. Cox and Cox (1990) research on the significant effect of store brand name, the brand, and the price discount on consumer value of a brand and purchase intention. It was discovered, that discount depth was adversely related to the perceived quality. The findings indicate that information of price promotion may not result in affirmative purchase intentions and can damage brand value.

Sivaramakrishnan and Manchanda (2003) studied on how rational consumers likely to assess the value of price discount offers, for instance product features such as; color, shapes, or sizes. It inferred that when buyers when have fewer product information, they assessed the brands and product value by attribute information such as; brand/product name, rather than on pricing to make a better purchase decision.

Though early scholars suggested the existence of campaign might lead to awareness in form in terms in inferior in value (Dodson, Tybout, \& Sternthal, 1978), outcomes of future work indicated that promotion's value information will be specific to context (Raghubir \& Corfman, 1999; Kahn \& Louie, 1990; Buil et al., 2013b). In current era, where mostly brands try to endorse, it is not likely that shoppers will mark adverse ascriptions about the product/brand existed on campaigns (sales promotions).

\subsubsection{Transaction Utility Theory}

Thaler (1985) depict that transaction total utility that resulting from purchase included transaction and acquisition utility, that proposed this model. Utility acquisition is the anticipated value gained after obtaining the (paybacks of) brand/product as associated to the price of the product. It can be expected that, utility transaction is the variance among the interior price reference of the product and the price purchase of it. It is consequent from the psychosomatic desire/pleasure on gaining experienced deal or bargain. Consumers were believed to have the familiarity in happiness from that they accepted the brand at a lesser price than its steady price. The model of utility transaction and acquisition was established from scholars, like, Lichtenstein, Netemeyer and Burton (1991) and Grewal and Monroe (1998).

Grewal and Monroe (1998) studied the effect of pricing comparing high to low advertising price on customer's perception in utility acquisition, behavioral intention and utility transaction. It has propose the comparing high to low advertise referred price may improve shopper's mental pleasure or utility transaction obtained in result of some transaction. Outcome indicate that associating lower to higher selling at external stated value would improve the perceived utility transaction and it may enhance consumer's perception for utility acquisition and willing-ness to buy the product/service. Lichtenstein, Netemeyer and Burton (1991) inspected the effect of vouchers on customer's perception on acquisition and transaction utilities. They establish that coupons would have better influence on the utility transaction than the acquisition. The occurrence of it is due to the lower pricing offered by vouchers was weighed besides the internal pricing reference. Customers associated the pricing at the level that they are receiving the service/product to the price internal referencing and it will lead to accompanying choice with monetary terms in transactions.

\subsubsection{Prospect Theory}

Diamond and Sanyal (1990) studied the prospect theory in context with consumer decision making, which proposes that individuals will recognize outcomes of a choice as observed in terms of 'losses' / 'gains' in their mind comparative to subject point reference. The theory anticipates that the price promotions will be observed abridged losses and will be selected less often than non- promotion based pricing, would be regarded as special advantage or as gains (theory first proposed by Kahneman \& Tversky, 1989). Nevertheless, Diamond and Sanyal (1990) later also establish that a nearly identical subject has preferred the pricing promotions (price discount) as matched to the (premium offer) non-price based promotions.

\subsubsection{Mental Accounting Theory}

The theory of mental accounting suggests the individuals conventionally make up psychological financial books in the mind to evaluate the costs (losses) in context to the final advantage they get in term of benefits or (gains) related to some transactions. Henderson and Peterson (1992) established that individuals have a tendency to group and have different labels' sources of revenue. Scholars have revealed that individuals assign expenses, income, and activities are to certain specific mental accounts in their thoughts (Shefrin \& Statman, 1987; Shefrin $\&$ Thaler, 1988; Heath \& Soll, 1996) and denigrate fixed costs of the expenditures in certain period and/or its use 
(Heath \& Fennema, 1996; Okada, 2001). Thaler and Johnson (1990) have studies that customers' observe unforeseen monetary influxes such as of sales promotion as in terms of some 'high gain/gains' and will consume margin's propensity at high level to consume as an anticipated income/s.

Mayhew and Winer (1992) studied the influence of price in context to, internal to external referencing (price in the mind) to external (prices by certain stimulus) on buyer product/brand choices. It was assess that the model-choices with variables that are in lieu of categories of reference values found to be had a substantial impact on purchase prospects of prices. Kalwani and Yim (1992) examined influence in term of brand promotional frequencies with its depth in the differences in prices on the brand's estimated price to the selection of a brand. It was established that both kinds of the promotion frequencies and the depth in context to the discounts would have substantial influence to the price prospects.

\subsubsection{Theory of Reasoned Action}

Shimp and Kavas (1984) has studied and implied the theory to know the customers' decision-making ability to make use of promotion in context to the coupon. Its outcome suggested that views in the advantage of using coupon/s will finally have greater positive relationship to buying or purchasing the attitude, while on the other hand the tiresomeness and hindrances would have fragile and/or/ negative correlation buying or purchasing the attitude. Authors have establish the conclusion that in both subjective and attitude norms applied vital impact to the purpose on purchase coupon/s. Study results have shown a strong relationship between the customer's intentions to purchase coupons and the stated actions (Buil et al., 2013a).

\subsubsection{Theory of Planned Behavior}

According to Jarvenpaa et al. (2000), the theory of planned behavior depicts that consumer is likely to buy from store (online), which is perceive to have low in risk, although the customer's attitudes toward the dealer may not be somewhat positive. In the context to the shopping on Internet, perceived risk may reduce buyer's perception of behavioral control to the extent to which a customer feels that appealing in a certain behavior is utterly up to him or her.

\subsubsection{The Attitude Theory}

Multi characteristic model related to attitude perceptions of the consumers (Fishbein \& Ajzen, 1975) represent the buyer's judgement making to achieve the behavior explicit to the rational significance in terms to attitudes, opinions in addition to intention to buy in context to the specific consumer deeds. As define by the classical attitude model, customer's intention to the product/brand to buy based on optimistic and/or adverse approaches toward the promotions.

These models provide significant perceptions for the customer decision thought process; some scholars have establish some incongruities in specified attitudes to real behavioral settings in some empirical works (Perry \& Gillespie, 1976; Keesling \& Kaynama, 2003). This predicts for possibly limited application of the attitude behavioral models for the examination of consumer's response to the promotion strategies/tactics.

\subsubsection{The Model of Elaboration Likelihood}

Scholars like; Inman, McAlister and Hoyer (1990) study the phenomenon of the Elaboration Likelihood to recommend psychological clarification on the subject of the promotional signals and price-cuts promotional effects to customer decision making for the specific product/brand choices. Elaboration Likelihood Model depict, the characteristics' ranges of behaviors through which decision choices could be exaggerate because of the stimuli exposure. The central route to persuasion for consumer decision-making actively and cognitively evaluates particular information. Furthermore, (Mittal, 1994) attempt to recognize the promotion sensitiveness to customer decision making in context to demographic features that, may not been fruitful, as response to promotion strategies.

\section{Promotion and Its Value}

Temporary price discounting and/or tactics are considered as a cradle to sway trial/sample offers for new product/brand.

\subsection{Why Sales to Promotion}

Temporary price discounting and/or tactics are considered as a cradle to sway trial/sample offers for new product/brand. Sample offers is consider as an initial footstep in the implementation model development, and branding mechanisms for customer that benefit the role in well distinct that may influence sample offers. Nevertheless, some discounts (price specific) also propose in-product groupings where it has miniature new brand overview activities. Consumer product classification and market consideration outline in table 1. 
Table 1. Consumer product classification and market consideration

\begin{tabular}{llll}
\hline Market Considerations & Convenience & Shopping & Specialty \\
\hline $\begin{array}{l}\text { Customer Buying } \\
\text { Behavior }\end{array}$ & $\begin{array}{l}\text { low customer involvements, } \\
\text { frequent buying, less } \\
\text { planning, little judgement or } \\
\text { shopping effort }\end{array}$ & $\begin{array}{l}\text { Low frequent purchase, } \\
\text { higher planning and shopping } \\
\text { determination specially for } \\
\text { comparison of brands and } \\
\text { prices quality, style }\end{array}$ & $\begin{array}{l}\text { Low price sensitivity, heavy } \\
\text { brand loyalty with preference, } \\
\text { special buying effort, miniature } \\
\text { comparison of products and/or } \\
\text { brands. }\end{array}$ \\
\hline Distribution and Price & $\begin{array}{l}\text { Low price, convenient } \\
\text { locations, general } \\
\text { distributions }\end{array}$ & $\begin{array}{l}\text { High price, Careful delivery } \\
\text { in less channels. }\end{array}$ & $\begin{array}{l}\text { Exclusive distribution in few } \\
\text { outlets per marketplace, High } \\
\text { price. }\end{array}$ \\
\hline Promotions & $\begin{array}{l}\text { Bulk campaign by the } \\
\text { manufacturer }\end{array}$ & $\begin{array}{l}\text { Personal selling with } \\
\text { advertising by the resellers } \\
\text { and producers }\end{array}$ & $\begin{array}{l}\text { More carefully niche promotion } \\
\text { by resellers and producer }\end{array}$ \\
\hline Examples & Laundry detergent, & $\begin{array}{l}\text { Major appliances, clothing, } \\
\text { furniture televisions }\end{array}$ & $\begin{array}{l}\text { Life style things, Expensive } \\
\text { men's wear, watches, athletic } \\
\text { shoes. }\end{array}$ \\
\hline
\end{tabular}

Source: Kotler P., and Garry Armstrong (2004).

Moreover, customs that bought the product earlier are often capitalize on these short-term inducements. Mostly in the context the product class categories, the practice of pricing and its discounting considered as predominant for traditional markets and for products, as it is same for the newly recently announced brands or freshly modified products or categories. Orthodox marketing understanding delivers us with scarce explanation for the phenomena. The short-term atmosphere of such spurs can be considered fascinating in many term regard to the context. What objectives can be achieved by the managers to offer discounts for the brands that emphasis on short-term time domain and can be consider as fragile in nature? Theoretical developmental decision-making studies for pricing strategies (for instance; Blattberg et al., 1981; Narasimhan, 1984, 1988; Raju et al., 1990; Lal, 1990a; Rao, 1991; Buil et al., 2013b) provide enlightenments for the prevalence of short-term pricing discounts in established marketplaces.

\subsection{Promotional Frequency and Depth}

Theoretical evolving decision-making developments in promotion strategies that focus to study the concerns in promotions based on the game theory decision-making and on econometrics models. These decision concepts are establish in econometrics theory that classically assume on the connected-lines rival businesses (e.g., Varian, 1980; Shilony, 1977). Accordingly, symmetric strategies for challengers considered indistinguishable in the decision principles. Types of consumers and derived results through promotion outline in table 2 .

Table 2. Types of consumers and derived results through promotion

\begin{tabular}{|c|c|c|}
\hline Type & Description & Derived Results \\
\hline Existing Loyal & $\begin{array}{l}\text { Individuals who buy the right brand most } \\
\text { of the time }\end{array}$ & $\begin{array}{l}\text { Rise consumption, modification purchase } \\
\text { judgement, Reinforce performance }\end{array}$ \\
\hline Loyal Competitive & Buy competitor's brand mostly & $\begin{array}{l}\text { Consumers who persuade to switch to some } \\
\text { other promoted product }\end{array}$ \\
\hline Switchers & $\begin{array}{l}\text { Individuals who shop many variety of } \\
\text { brands at category level }\end{array}$ & $\begin{array}{l}\text { Consumers who are persuaded to shop the } \\
\text { brand "right" for them }\end{array}$ \\
\hline $\begin{array}{l}\text { Specific Price } \\
\text { Consumers }\end{array}$ & $\begin{array}{l}\text { Consumers who shop the minimum } \\
\text { expensive product }\end{array}$ & $\begin{array}{l}\text { Supply based value for a product that make } \\
\text { less importance to price }\end{array}$ \\
\hline
\end{tabular}

Source: Schultz, Don. E., William, Robinson, A., Lisa, Petrison, (1998).

Enlightenments on the specific product may promote additional insights that are better than the rival's symmetries in marketplaces with unequal rivals. Narasimhan (1988), Raju, Srinivasan and Lal (1990), and Agrawal (1994) study specific developments with regard to econometrics studies on several different backgrounds. The decision theories and its study explain some vital transformations in context to promotional strategies through products and cross branding strategies to marketplace and symmetry products physiognomies. 
The structures reflected in the context are:

(i) Switching segment size,

(ii) Loyal customers to/or brand loyalty,

(iii) Effectiveness in advertising strategies/tactics.

\subsection{Consumer Response to Promotions}

Preceding empirical researches in thinking process for consumers and marketing effort mostly focus on customer response in context with promotions via approaches in experimentations (Doob et al., 1969; Dodson et al., 1978; Kahn \& Raju, 1991). Some economics examine the secondary measurements (for instance, Guadagni \& Little, 1983; Neslin et al., 1985; Krishnamurthi \& Raj, 1988; Jain \& Vilcassim, 1991; Buil et al., 2013a). However, few have made an attempt for understanding customer reaction via sales promotions models by means of theoretical decision making models, such as few empirical studies of Assuncao and Meyer (1993), Helsen and Schmittlein (1992), Krishna (1992) and Buil et al. (2013b).

\section{Concluding Remarks and Future Direction}

Theoretical decision-making models and theories in context to promotions at both brand and product level have focused and studied on several thought-provoking research explorations, though preliminary attention is on concerns for instance, why businesses find it best to practice sales promotions strategies at customary marketplaces. In recent era, micro level studies are the targets for the corporations and for the empirical investigators to focus on consumer in context to behavior judgments, stockpiling, price discounts, pricing depths and price breath from its frequency to its time domain with brand loyalty, loyal consumers, decision stimulus and advertising sensitivity. Developmental theoretical models provide managers and researchers insights with deep understandings for many vital concerns like, why need in-depth study to the practice of promotion strategies, dilemmas like stock pressure, sales promoting decline after promotion events and its consequences. Branding and pricing has vital influence on decisions by consumers. Psychophysiological models are useful in the context, for instance, in decision and media research. These models provide as an insight favorable apparatus for research in pricing as well. These models also enlighten us with new evidence and empower the academicians for novel magnitudes in traditional marketing pricing hitches.

\section{References}

Agrawal, D. (1994). Effect of brand loyalty on advertising and trade promotions: A game theoretic analysis with empirical evidence. Marketing Science, 15(1), 86-108. http://dx.doi.org/10.1287/mksc.15.1.86

Assuncao, J. L., \& Meyer, R. J. (1993). The rational effect of price promotions on sales and consumption. Management Science, 39(5), 517-535. http://dx.doi.org/10.1287/mnsc.39.5.517

Bearden, W. O., Lichtenstein, D. R., \& Teel, J. E. (1984). Comparison Price, Coupon and Brand Effects on Consumer Reactions to Retail Newspaper Advertisements. Journal of Retailing, 60(2), 11-35. http://dx.doi.org/10.1016/S0022-4359(99)80099-2

Berkowitz, E. N., \& Walton, J. R. (1980). Contextual Influences on Consumer Price Responses: An Experimental Analysis. Journal of Marketing Research, 17(3), 349-359. http://dx.doi.org/10.2307/3150533

Blattberg, R. C., Eppen, G. D., \& Lieberman, J. (1981). A theoretical and empirical evaluation of price deals for consumer Nondurables. Journal of Marketing, 45(winter), 116-129.

Blattberg, R., Briesch, R., \& Fox, E. J. (1995). How Promotions work. Marketing Science, 14(3), 122-132. http://dx.doi.org/10.1287/mksc.14.3.G122

Buil, I., Martínez, E., \& Chernatony, L. (2013a). Examining the role of advertising and sales promotions in brand equity creation. Journal of Business Research, 66(1), 115-122. http://dx.doi.org/10.1016/j.jbusres.2011.07.030

Buil, I., Martínez, E., \& Chernatony, L. (2013b). The influence of brand equity on consumer responses. Journal of Consumer Marketing, 30(1), 62-74. http://dx.doi.org/10.1108/07363761311290849

Campbell, L., \& Diamond, W. D. (1990). Framing and Sales Promotion: the Characteristics of a Good Deal. Journal of Consumer Marketing, 7(4), 25-31. http://dx.doi.org/10.1108/EUM0000000002586

Chandon, P., Brian, W., \& Gilles, L. (2000). A Benefit Congruency Framework of Sales Promotion Effectiveness. Journal of Marketing, 64(4), 65-81. http://dx.doi.org/10.1509/jmkg.64.4.65.18071

Cox, A. D., \& Cox, D. (1990). Competing on Price: The role of retail price advertisements in shaping store-price 
image. Journal of Retailing, 66(4), 428-445.

Davis, S. J., Inman, J., \& McAlister, L. (1992). Promotion has a Negative Effect on Brand Evaluations - or Does it? Journal of Marketing Research, 29(1), 143-149.

Diamond, W. D., \& Sanyal, A. (1990). The Effect of Framing on Choice of Supermarket Coupons. Advances in Consumer Research, 17, 488-493.

Dickson, P. R., \& Sawyer, A. G. (1990). The Price Knowledge and Search of Supermarket Shoppers. Journal of Marketing, 54(3), 42-53.

Dodson, J. A., Tybout, A. M., \& Sternthal, B. (1978). Impact of Deals and Deal Retraction on Brand Switching. Journal of Marketing Research, 15, 72-81. http://dx.doi.org/10.2307/3150402

Doob, A., Carlsmith, J., Freedman, J., Landauer, T., \& Tom, S. (1969). Effect of initial selling price on subsNuent sales. Journal of Personality and Social Psychology, 11(July), 345-350.

Ehrenberg, A. S. C., Hammond, K., \& Goodhardt, G. J. (1994). The after-effects of Price Related Consumer Promotions. Journal of Advertising Research, 34, 11-21.

Fishbein, M., \& Ajzen, I. (1975). Beliefs, Attitude, Intention, and Behavior: An Introduction to Theory and Research. Reading, MA: Addison Wesley.

Grewal, D., \& Monroe, K. B. (1998). The Effect of Price Comparison Advertising on Buyers' Perception of Acquisition Value, Transaction Value and Behavioral Intentions. Journal of Marketing, 62(2), 46-60.

Guadagni, P. M., \& Little, J. D. C. (1983). A Logit Model of Brand Choice Calibrated on Scanner Data. Marketing Science, 2, 203-238.

Guadagni, P. M., \& Little, J. D. C. (1983). A logit model of brand choice calibrated on scanner data. Marketing Science, 3(Summer), 203-238.

Gurumurthy, K., \& Winer, R. S. (1995). Empirical Generalizations from Reference Price Research. Marketing Science, 14(3), 161-170. http://dx.doi.org/10.1287/mksc.14.3.G161

Heath, C., \& Fennema, M. G. (1996). Mental Depreciation and Marginal Decision Making. Organization Behavior and Human Decision Processes, 66(2), 95-105.

Heath, C., \& Soll, J. B. (1996). Mental Accounting and Consumer Decisions. Journal of Consumer Research, 23, $40-52$.

Helsen, K., \& Schmittlein, D. (1992). Some characterizations of stockpiling behavior under uncertainty. Marketing letters, 3, 5-16. http://dx.doi.org/10.1007/BF00994076

Huff, L., \& Alden, D. L. (1998). An Investigation of Consumer Response to Sales Promotion in Developing Markets: A Three-Country Analysis. Journal of Advertising Research, 38(3), 47-56.

Inman, J. J., McAlister, I., \& Hoyer, W. D. (1990). Promotion Signal: Proxy for a Price cut? Journal of Consumer Research, 17, 74-81.

Jain, D. C., \& Vilcassim, N. J. (1991). Investigating household purchase timing decisions: A conditional hazard function approach. Marketing Science, 1-23. http://dx.doi.org/10.1287/mksc.10.1.1

Jarvenpaa, S. L., Tractinsky, N., \& Vitale, M. (2000). Consumer Trust in an Internet Store. Information Technology \& Management, 1(1-2), 45-71.

Kahn, B. E., \& Raju, J. S. (1991). Effects of price promotions on variety-seeking and reinforcement behavior. Marketing Science, 10(4), 316-337.

Kahn, B., \& Louie, T. A. (1990). Effects of Retraction of Price Promotions on Brand Choice Behavior for Variety seeking and Last Purchase Loyal Consumers. Journal of Marketing Research, 27(3), 279-289.

Kahneman, D., \& Tversky, A. (1989). Prospect Theory: An Analysis of Decision under Risk. Econometrica, 47, 263-291.

Kalwani, M. U., \& Yim, C. H. (1992). Consumer Price and Promotion Expectations. Journal of Marketing Research, 29(1), 90-100.

Kalwani, M. U., Rinne, H. J., Sugita, Y., \& Yim, C. K. (1990). A Price Expectations Model of Consumer Brand Choice. Journal of Marketing Research, 27, 251-262.

Kamakura, W., \& Russell G. J. (1989). A Probabilistic Choice Model for Market Segmentation and Elasticity 
Structure. Journal of Marketing Research, 26(4), 379-391.

Keesling, G., \& Kaynama, S. A. (2003). An Exploratory Investigation of the Ecologically Conscious Consumers efforts to control water contamination: Lawn care and the use of nitrogen fertilizers and pesticides. Journal of Marketing Theory \& Practice, 11(1), 52-62.

Kotler, P., \& Armstrong, G. (2004). Principles of Marketing. New Delhi: Pearson Education.

Krishna, A. (1992). The normative impact of consumer price expectations for multiple brands on consumer purchase behavior. Marketing Science, 11(3), 266-286.

Krishnamurthi, L., \& Raj, S. P. (1988). A model of brand choice and purchase quantity price sensitivities. Marketing Science, 7(1), 1-20.

Lal, R. (1990a). Price promotions: Limiting competitive encroachment. Marketing Science, 9, 247-262.

Lattin, M. J., \& Bucklin, R. E. (1989). Reference Effects of Price and Promotion on Brand Choice Behaviour. Journal of Marketing Research, 26, 299-310.

Lichtenstein, D. R., Netemeyer, R. G., \& Burton, S. (1991). Using a Theoretical Perspective to Measure the Psychological Construct of Coupon Proneness. Advances in Consumer Research, 18(1), 501-507.

Martin, M., \& Monroe, K. B. (1994). Perceived price fairness: A new look at an old construct. Advances in Consumer Research, 21, 75-78.

Mayhew, G. E., \& Winer, R. S. (1992). An Empirical Analysis of Internal and External Reference Prices using Scanner Data. Journal of Consumer Research, 19, 62-71.

Mittal, B. (1994). An Integrated Framework for Relating Diverse Consumer Characteristics to Supermarket Coupon Redemption. Journal of Marketing Research, 31, 533-544.

Mizerski, L., Golden, L., \& Kernan, J. B. (1979). The Attribution Process in Consumer Decision Making. Journal of Consumer Research, 6(September), 123-140.

Monroe, K. B. (1973). Buyers' Subjective Perceptions of Price. Journal of Marketing Research, 10(1), 70-80.

Narasimhan, C. (1984). A price discrimination theory of coupons. Marketing Science, 312(Spring), 128-147. $\mathrm{http}: / / \mathrm{dx}$.doi.org/10.1287/mksc.3.2.128

Narasimhan, C. (1988). Competitive promotional strategies. Journal of Business, 61(October), 427-450.

Neslin, S. A., \& Shoemaker, R. W. (1989). An Alternative Explanation for Lower Repeat Rates after Promotion Purchases. Journal of Marketing Research, 26, 205-213.

Neslin, S. A., Henderson, C., \& Quelch, J. (1985). Consumer promotions and the acceleration of product purchases. Marketing Science, 4(Spring), 147-165. http://dx.doi.org/10.1287/mksc.4.2.147

Okada, E. M. (2001). Trade-Ins, Mental Accounting and Product Replacement Decisions. Journal of Consumer Research, 27, 433-446.

Perry, R. W., \& Gillespie, D. F. (1976). An Analysis of the Intervening Variables in the Attitude-Behavior Relationship. Journal of Social Psychology, 98(2), 287-289.

Raghubir, P., \& Corfman, K. (1999). When do Price Promotions Affect Pre-Trial Brand Evaluation. Journal of Marketing Research, 36, 211-222.

Raju, J. S., Srinivasan, V., \& Lal, R. (1990). The effects of brand loyalty on competitive price promotional strategies. Management Science, 36(3), 276-304. http://dx.doi.org/10.1287/mnsc.36.3.276

Rao, R. C. (1991). Pricing and promotions in asymmetric duopolies. Marketing Science IO, 131-144. http://dx.doi.org/10.1287/mksc.10.2.131

Schultz, D. E., Robinson, W. A., \& Petrison, L. (1998). Sales Promotion essentials: the 10 basic sales promotion techniques-and how to use them (3rd ed.). New York: The McGraw-Hill.

Shefrin, H. H., \& Thaler, R. H. (1988). The Behavioral Life Cycle Hypothesis. Economic Inquiry, 26, 609-643.

Shefrin, H., \& Statman, M. (1987). Explaining Investor Preference for Cash Dividends. Journal of Finance, 40, 777-790.

Shilony, Y. (1977). Mixed pricing in an oligopoly. Journal of Economic Theory, 14(April), 373-388.

Shimp, T. A., \& Alican, K. (1984). The Theory of Reasoned Action Applied To Coupon Usage. Journal of Consumer Research, 11(December), 795-809. 
Shoemaker, R. W., \& Shoaf, F. R. (1977). Repeat Rates of Deal Purchases. Journal of Advertising Research, 17, 47-53.

Sivaramakrishnan, S., \& Manchanda, R. V. (2003). The effect of cognitive busyness on consumers' perception of product value. Journal of Product and Brand Management, 12(5), 335-345.

Thaler, R. H. (1985). Mental Accounting and Consumer Choices. Marketing Science, 4(3), 199-214. http://dx.doi.org/10.1287/mksc.4.3.199

Thaler, R. H., \& Johnson, E. J. (1990). Gambling with the House Money and Trying to Break Even: The Effects of Prior Outcomes on Risky Choice. Management Science, 36, 643-660. http://dx.doi.org/10.1287/mnsc.36.6.643

Urbany, J. E., Bearden, W. O., \& Weilbaker, D. C. (1988). The Effect of Plausible and Exaggerated Reference Prices on Consumer Perceptions and Price Search. Journal of Consumer Research, 15(1), 95-111.

Varian, H. R. (1980). A model of sales. American Economic Review, 70(September), 651-659.

Winer, R. S. (1986). A Reference Price Model of Brand Choice for Frequently Purchased Products. Journal of Consumer Research, 13, 250-256.

\section{Copyrights}

Copyright for this article is retained by the author(s), with first publication rights granted to the journal.

This is an open-access article distributed under the terms and conditions of the Creative Commons Attribution license (http://creativecommons.org/licenses/by/3.0/). 